\title{
HOLDING UP A MIRROR TO APARTHEID SOUTH AFRICA: PUBLIC DISCOURSE ON THE ISSUE OF OVERCROWDING IN SOUTH AFRICAN PRISONS 1980 TO 1984 - PART 2
}

\author{
Stephen Allister Peté \\ BA LLB LLM MPhil \\ Associate Professor of Law, Faculty of Law \\ Howard College Campus \\ University of KwaZulu-Natal, Durban \\ Attorney of the High Court of South Africa
}

\section{SUMMARY}

During the first half of the 1980s, the issue of chronic overcrowding within the South African penal system formed part of an intense ideological struggle between those who supported and those who opposed the apartheid regime. Public debate around this issue acted as a mirror, reflecting early cracks which were beginning to appear in the edifice of apartheid. Since the prisons were the ultimate instrument of social control within the apartheid system, the ongoing crises caused by chronic overcrowding within these institutions served as a kind of "canary in the mine" for the apartheid system as a whole. The debates which took place during the early 1980 s around overcrowding are also important because they form part of a common theme running through South African penal discourse as a whole. This article seeks to show how the debates on prison overcrowding which took place in the first half of the 1980 s fit into a long-term pattern of recurring ideological crises surrounding this issue. The article is divided into two parts. In Part One, the above themes were explored through the public discourse surrounding the Steyn Commission of Enquiry into the public media, as well as the Hoexter Commission of Enquiry into the structure and functioning of South Africa's courts. Whereas Part One deals only with certain early debates arising out of the Hoexter Commission - up to February 1981 Part Two takes this as a starting point and traces a number of further themes which arose in the debates surrounding the Hoexter Commission between February 1981 and April 1984, when the Commission delivered its report.

\section{INTRODUCTION}

The purpose of this article is to analyze the ideological struggle waged in the mass media between 1980 and 1984 on the issue of overcrowding in South African prisons. Although debates on the issue of prison overcrowding were only one of many ideological struggles being waged at the time, the debates are interesting and significant for at least two reasons: In the first place, it is 
contended that public debates on the issue of prison overcrowding throughout the first half of the 1980s held up a mirror to South African society, in which those willing to look could see reflected the inevitable demise of the apartheid system. In the second place, it is argued that these debates tie in with a much broader and longer-term public and academic discourse on the issue of prison overcrowding, leading to the conclusion that there is an inextricable link between imprisonment as a form of punishment and chronic overcrowding of prisons. This link is apparent throughout the penal history of South Africa, whether one is examining the colonial period, the apartheid period, or the post-apartheid period, and the debates are characterized by the repeated identification of the same problem, together with the same set of "solutions", which are repeated year after year, decade after decade, and from one century to the next.

In part one of this article, both themes mentioned above were explored through an analysis of different aspects of the public debates on prison overcrowding which took place during the early 1980s. In particular, part one examined critical debates on the legislative restrictions which prevented free reporting about conditions in South African prisons at the time. It was pointed out that the general debate on prison overcrowding provided a platform for a wide range of commentators to express concern about the dangers of censorship in apartheid South Africa. Part one also tapped into a rich series of public debates, conducted in a variety of national newspapers despite the legislative restrictions in place, on the link between prison overcrowding and the continued enforcement of apartheid social-control measures such as influx control and the pass laws. It was pointed out that the debates on prison overcrowding acted as a mirror to ordinary South Africans, particularly white middle-class South Africans who were the main beneficiaries of the apartheid system, revealing to them the moral bankruptcy of the system, as well as the fact that the system was untenable in the medium to long term. Finally, part one made the link between the debates on prison overcrowding which took place in the early 1980s, and similar debates which took place at other times in South Africa's penal history. It was pointed out that chronic overcrowding seems to be inextricably, perhaps even structurally, linked to imprisonment as a form of punishment in South Africa.

Part two of this article will continue to explore the broad themes unearthed in part one and mentioned briefly above. In the section which follows a number of themes will be examined, which emerged in the public debate after General Brink's evidence before the Hoexter Commission. These themes include the legacy of hatred which was being created by the imprisonment of large numbers of "social-control offenders"; a diminution in the deterrent effect of sentences of imprisonment by imprisoning too many ordinary citizens, guilty only of trying to make a living in the land of their birth; the creation of "Universities of Crime" by imprisoning too many petty offenders alongside "real" criminals; and concern over negative global perceptions of the supposedly "civilized" South African penal system. The section after that will trace the development of the public debate on prison overcrowding, from the time the debate calmed down following the furore created by General Brink in February 1981, until the Hoexter Commission delivered its report in April 1984. The next section will trace a second 
explosion in the debate, caused by the release of the Hoexter Commission report. The final section will discuss corporal punishment as one of the proposed "solutions" to the problem of chronic overcrowding. The article will conclude by drawing together all themes discussed.

\section{A LEGACY OF HATRED, REDUCED DETERRENCE, THE CREATION OF "UNIVERSITIES OF CRIME" AND CONCERN OVER GLOBAL PERCEPTIONS}

The focus of the final section in part one of this article was on the fact that most commentators who took part in the public debate on prison overcrowding which followed the evidence of General Brink before the Hoexter Commission, had come to believe that the continued use of prisons to enforce apartheid social-control legislation was untenable. This section will explore certain central themes which were raised over and over again in the debate to illustrate the negative consequences of allowing persons who were "technical offenders" against social control legislation, or persons driven by poverty to commit petty offences, to be incarcerated alongside "real criminals" in the country's overcrowded prisons.

The first theme concerns the legacy of hate which was an inevitable byproduct of a system using prisons as a means of social control. Since only "non-white" South Africans were subject to imprisonment for committing offences against social control measures, and since the measures targeted normal law-abiding citizens who simply wished to find employment, the branding of such persons as "criminals" was deeply resented by the overwhelming majority of black South Africans. As was to be expected, reports in the "black press" at this time confirmed the view that the system was creating a legacy of hatred. For example, a Soweto social worker, Mr Shimane Khumalo, was quoted in The Sowetan as follows:

"Only 10 percent of people sent to jail need to be there, and these are the dangerous criminals whose imprisonment is for their own protection and the protection of society. But other people who commit trivial technical offences could be kept out of jail by being placed under the supervision of a probation officer while being made to do community service. My opposition to sentencing people to jail is because jail makes people bitter. You will sometimes find that people who are jailed for minor offences, come out of prison being more sophisticated in their criminal ways."

This view was shared wholeheartedly by commentators in the mainstream "white" press - both English and Afrikaans. Time and again commentators made the point that the apartheid system of social control was creating a legacy of bitterness which would haunt South Africa for years to come. For example, Die Transvaler pointed out that imprisonment for offences against "administrative legislation" (that is, apartheid social-control measures) held serious long-term implications for sound race relations in the country. ${ }^{2}$ Another Afrikaans language newspaper, Rapport, pointed to the thousands

"Concern Over Extent of Prison Overpopulation" 6 February 1981 The Sowetan 1.

2 "Ernstige Misstand" 6 February 1981 Die Transvaler 8. 
of ordinary breadwinners that were forced to sit in jail for weeks on end purely on account of technical offences, and commented dramatically as follows:

"This is how we cultivate hate. This is how we cultivate rage. This is how we cultivate contempt for authority."

Even more conservatively inclined Afrikaans-language newspaper editors agreed that using prisons to enforce apartheid social-control measures was leading to race hatred. For example, an editorial in the Afrikaans-language newspaper Die Vaderland stated that it was a common perception among back people that "it is 'them', the white people, who so regularly throw 'us', the black people, into prison". "What comes through in this editorial is the real fear among certain sections of the "white" community, that imprisoning thousands of ordinary South Africans for offences against social-control measures put in place by the apartheid regime, was creating a whirlwind of bitterness and resentment which would come back to haunt South Africa in the future.

The second theme to be examined concerns the reduction in the deterrent effect of imprisonment which was seen to result from imprisoning very large numbers of ordinary persons for petty offences, many of them political, which they could not reasonably avoid. By subjecting large numbers of normal law-abiding citizens to imprisonment for violating ideologically motivated measures of social control, or other petty rules and regulations, it was pointed out that the punishment of imprisonment would lose its stigma, and thus its deterrent effect, particularly in the minds of black South Africans. This view is well illustrated in an editorial which appeared in Die Vaderland at this time, which set out its opinions on this point in blunt and frankly racist terms. According to the editorial, the scale of pass offences meant that imprisonment had become a way of life for "the black man". Imprisonment was no longer a deterrent for "the black man" because no stigma attached to "a black who was in prison", either in the eyes of "his own community" or in the eyes of "whites who employed him". This had serious consequences for South Africa with its "big black and small white" population, since it led to polarization between white and black. ${ }^{5}$ Essentially the same view was expressed in many of the more mainstream English and Afrikaans language newspapers, although with less of a racist overtone. For example, Die Transvaler stated that if it was too easy for offenders to end up in prison for nominal offences, it had the effect of "cheapening" the punishment of imprisonment, which eroded the stigma attached to such punishment together with its deterrent effect. ${ }^{6}$ The Natal Mercury made the same point as follows:

3 "So Kweek ons Haat. So Kweek ons Woede. So Kweek ons Minagting vir Gesag". See "Volle punt, Regte H!" 8 February 1981 Rapport 18.

"Oorbevolkte Tronke" 6 February 1981 Die Vaderland 10.

Ibid.

6 "As oortreders te maklik vir geringe oortredings in die gevangenis beland, het dit ook die uitwerking dat tronkstraf 'goedkoop' gemaak word. Dit verweer die stigma daaraan verbonde en gevolglik ook die efektiwiteit daarvan as afskrikmiddel." See 6 February 1981 Die Transvaler 8. 
"[l]mprisonment - one in four adult blacks being arrested each year on technical offences - no longer carries much stigma in the black community at all. The law, therefore, has been brought into contempt."

The Mercury castigated the apartheid government for its "dictatorial and authoritarian attitude" as well as its "only passing concern for the unnecessary human suffering and degradation caused by respectable people being imprisoned for technical offences ..."8

The third theme to be examined concerns the idea that South African prisons had become "universities of crime". Many commentators in the early 1980s expressed the idea that, far from curbing crime, the South African penal system was in fact leading to an increase in the country's crime rate. In other words, South African prisons were regarded by many as being "universities" or "schools" of crime, rather than places where criminals were rehabilitated. The incarceration of far too many petty offenders, most of whom did not really belong in prison, together with chronic overcrowding in the penal system, were regarded as crucial factors in a cycle which was not only negative, but also fed on itself. A good example of the way in which commentators saw the negative self-reinforcing cycle to be operating is to be found in the following extract from an editorial in The Citizen:

"Courts jail more and more people, who go into more and more overcrowded prisons. Petty offenders come into contact with hardened criminals and become more prone to crime rather than chastened by their incarceration. Instead of prisoners being rehabilitated, more and more are recidivists, people who commit further crimes and return to jail. We cannot blame the prison authorities. They do their best. The system is such that jail is not a deterrent, but helps increase crime rather than reduce it ... Shouldn't the whole object be to keep as many people out of jails rather than put as many people as possible in them? Shouldn't we be looking at our system of punishment to see that it is less punitive and more rehabilitative? Shouldn't we stop sending to jail people convicted of relatively minor offences? ... As it is, we are simply breeding crime and criminals. And no country can afford to have as many people in jail as we have."

Another example within the public discourse at the time which put forward the view that South African prisons were incubators of crime, rather than places in which criminals were rehabilitated, appeared in Die Vaderland. The newspaper quoted a criminologist at the University of South Africa, Professor Piet van der Walt, as stating that it had been proved repeatedly all over the world that sentences of imprisonment for petty offences promoted crime. Petty offenders came into contact with hardened criminals in prison, who then recruited them and led them into the underworld. Professor Van der Walt pointed out that more than 80 per cent of South Africa's prison population were imprisoned for less rather than more serious offences, and that a disturbing percentage of the prisoners were awaiting trial. $\mathrm{He}$ explained that fines were an alternative to imprisonment, but pointed out that most offenders were in no position to pay fines, which meant that they ended up in prison for a week or two. This provided the hardened criminals in

\footnotetext{
"Prison Time Bomb" 6 February 1981 The Natal Mercury.

Ibid.

"Out Not In" 6 February 1981 The Citizen 6.
} 
prison with an ideal opportunity to recruit "new blood" ${ }^{10}$ Similar views were expressed by other public commentators at this time, who drew attention to a statement made by General Brink before the Hoexter Commission, to the effect that awaiting-trial prisoners could spend as long as seven weeks in jail and then receive sentences as little as a fine of R4 or 10 days imprisonment. The Natal Mercury expressed the opinion that this was "the most chilling statement" by General Brink in his evidence to the Hoexter Commission and pointed out that: "The effect on petty offenders ... has not been to reduce their numbers but increase them and while doing so bring into contempt laws, many of which social scientists and lawyers feel should be scrapped." An editorial in the Evening Post stated that, one way to reduce prison populations was "to end the system in which awaiting-trial prisoners, which make up about $15 \%$ of prison inmates, spend weeks in jail before receiving sentences of as little as R4 fines or 10 days' imprisonment". ${ }^{12}$ The problem of large numbers of awaiting-trial prisoners, as well as prisoners remaining in jail because they could not afford bail, was to continue long into the post-apartheid period. ${ }^{13}$

A final theme which may be mentioned before concluding this section relates to the global political context within which the debate in question was taking place. An interesting strand in the discourse surrounding chronic overcrowding in South African prisons at the time of General Brink's evidence before the Hoexter Commission in the early 1980s, was the concern expressed by some commentators as to how his revelations would be perceived by the outside world. The Natal Mercury, for example, called the chronic overcrowding a "sickening blot on the country's image". ${ }^{14}$ An editorial in the Afrikaans language newspaper Beeld stated, inter alia, that the overcrowded conditions in South African prisons could not be allowed to continue if South Africa wanted to avoid being accused of running a prison system which could not "pass the test of civilised norms". ${ }^{\text {t5 }}$ Clearly, ideological pressure against the apartheid system had been building,

\section{February 1981 Die Vaderland 1. \\ 6 February 1981 The Natal Mercury. \\ "Prison Overcrowding: Govt must Act Now" 5 February 1981 Evening Post 6.}

13 See, in general, Peté "The Politics of Imprisonment in the Aftermath of South Africa's First Democratic Election" 19981 South African Journal of Criminal Justice 51-83; and Peté "The Good the Bad and the Warehoused - The Politics of Imprisonment During the Run-up to South Africa's Second Democratic Election" 2000 13(1) South African Journal of Criminal Justice 1-56; and Peté "Between the Devil and the Deep Blue Sea - The Spectre of Crime and Prison Overcrowding in Post-apartheid South Africa" 2006 27(3) Obiter 429-453. A related issue which received some mention during the period under examination, but which was to become a much more prominent part of the public debate during the post-apartheid period, was that of the negative effect of minimum-sentencing legislation on the South African prison population. One example of this issue being raised in the early 1980 s is to be found the following extract from the Rand Daily Mail: "[A]s the Prisons Department notes, five-year sentences for minor drug offences plus the system of compulsory indeterminate sentences are clogging the prisons - while their effect in deterring others is problematical" in "Getting to Grips with the Prisons Crisis" 9 February 1981 Rand Daily Mail 6.

146 February 1981 The Natal Mercury.

15 "[T]oestande [is] aan die lig gebring wat nie ongehindered toegelaat kan word om voort te duur as ons nie daarvan beskuldig wil wees dat ons gevangenisse nie die toets van beskaafde norme kan deurstaan nie" in "Gevangenisles" 6 February 1981 Beeld 8. 
worldwide, for many years, making the perceptions of the outside world a particularly sensitive point for those (white) South Africans who supported the status quo. This appeal to "civilized values" is, interestingly, somewhat reminiscent of calls made during the post-apartheid period to ensure the prison overcrowding did not render the living conditions in South African prisons so bad that they amounted to a breach of the fundamental human rights of prisoners as enshrined in the constitution.

\section{THE DEVELOPMENT OF THE DEBATE AFTER FEBRUARY 1981}

Having examined the upsurge in public debate on the issue of prison overcrowding which occurred with the evidence of General Brink before the Hoexter Commission in February 1981, the section which follows will provide a broad overview of the manner in which the debate developed from that point, until the report of the commission became available in April 1984.

In May 1981, an editorial in The Natal Mercury commented on the activities of the working group which had been established by the Department of Justice to investigate overcrowding in South Africa's prisons. The chairperson of the working group was the Chief Magistrate of Pretoria, Mr WF Krügel. The editorial began with the startling allegation that "South Africa's staggeringly large prison population of 440 per 100000 " was "more than twice that of any other country in the Free World". ${ }^{16}$ It then went on to bemoan the seeming inability of the Government to address the problem of overcrowding in the prisons which had been apparent for many years. A sense of the frustration felt by many commentators at this time - particularly those in the "liberal" press - is apparent in the following extract from the editorial:

"[O]ne cannot help feeling that the establishment of ... [the] working group ... is more a measure of the Government's desperation than a promising excursion into new territory. For more years than we care to remember, the prison authorities, lawyers, politicians, academics and other concerned bodies and individuals have been voicing their alarm over the country's ever-growing prison population ... The departmental working group ... may turn up something new in this exhaustively tilled field, but what is really needed is not more information and opinions but some urgent Government action on the glaring facts already known."

One cannot help but feel sympathy for the view expressed by the editor of The Natal Mercury. Similar debates about chronic overcrowding in South African prisons had been taking place since colonial times, and were to continue well into the post-apartheid period, without any resolution to the problem. Indeed, The Natal Mercury's description of the debates on the problem as being an "exhaustively tilled field", seems an apt description not only of debates which took place during the apartheid period, but also of

16 "Crowded Jails" 25 May 1981 The Natal Mercury 14.

17 Ibid. 
similar debates which took place during the colonial and post-apartheid periods. ${ }^{18}$

In June 1981, the national chairman of the National Institute for Crime Prevention and Rehabilitation, Mr Justice Kumleben, told the annual meeting of the organization that South Africa's prisons were grossly overcrowded and that: "The gravity of the situation can hardly be overstated." ${ }^{19} \mathrm{He}$ then spoke of the need to develop alternatives to imprisonment, which he said should be a form of punishment reserved primarily for isolating "chronically dangerous persons" from society. ${ }^{20}$ An editorial in The Natal Mercury expressed cautious approval of Judge Kumleben's views:

"We could not agree more with the Judge's basic concept of seeking acceptable and workable alternatives to imprisonment, but obviously the crimes which would qualify for non-custodial sentences would need some careful study, and frankly we would question the merit of allowing all but 'chronically dangerous persons' to escape the time-honoured punishment and stigma of being removed from society for their crimes ... But that is a matter of opinion on where to draw the line. The fact remains that a great many people who appear in South African courts do not pose any threat to the community, yet they face imprisonment because there is no more enlightened means available to deal with them."

In the months which followed, the point that South Africa's prisons were clogged up with too many petty offenders, particularly people guilty of technical offences against apartheid social-control legislation, was made time and again. For example, the following comments were made in two different national newspapers in July 1981:

"[M]any of the people who are in jail should not be there at all. Far too many are accused only of technical offences under the pass laws.'

"Whatever the long-term solution, there is no doubt that pass laws, invariably undesirable in themselves, are a major factor in prison overcrowding and create a host of unpleasant by-products. The need for a review is urgent."

It is interesting to note that precisely the same sentiments were to be expressed, almost two decades later, in debates on the issue of chronic overcrowding in the prisons of post-apartheid South Africa. ${ }^{24}$ The same problem and the same suggested "solutions" were to be recycled decade after decade, over and over again. ${ }^{25}$

18 See, in general, Peté 19981 South African Journal of Criminal Justice 51-83; Peté 2000 13(1) South African Journal of Criminal Justice 1-56; Peté 2006 27(3) Obiter 429-453; and see also Peté "Like a Bad Penny: The Problem of Chronic Overcrowding in the Prisons of Colonial Natal 1845 to 1910 - Parts One and Two" forthcoming publications.

"Overcrowing of Prisons Grave, says Durban Judge" 18 June 1981 The Daily News 10.

"To Fit the Crime" 19 June 1981 The Natal Mercury 12.

Ibid. See also "Prison Reform" 20 June 1981 The Daily News 6.

"Vicious Circle" 8 July 1981 The Argus 12.

"People Behind Bars" 9 July 1981 The Cape Times 12.

See, in general, Peté 19981 South African Journal of Criminal Justice 51-83; Peté 2000 13(1) South African Journal of Criminal Justice 1-56; and Peté 2006 27(3) Obiter 429-453.

25 One suggestion which was regularly put forward as a means of easing the chronic overcrowding in South Africa's prisons, was to replace sentences of imprisonment with sentences of community service in suitable cases. The idea was that imprisonment should 
In May 1982 the issue of chronic overcrowding in South Africa's prisons once again reared its head in the public media. In the discussion of his annual report in Parliament, the Director-General for Justice, Mr JPJ Coetzer, revealed that in February of the previous year the average daily prison population in South Africa was 104622 inmates, whereas the prison system was designed to accommodate only 75576 inmates. He stated that the figure of 104622 prisoners was "the highest figure ever recorded in the history of this country". ${ }^{26}$ Some success had been achieved in reducing the average daily prison population from this all time high. By May 1981 the average daily prison population had fallen to 99581 inmates, a decrease of 4,8 percent. An amnesty granted to certain prisoners on 31 May 1981 further reduced the prison population so that, by 30 June 1981, only 82706 inmates were imprisoned in South African jails. ${ }^{27}$ This relatively "good news" was, however, not to prove very long-lasting in its effect.

By June 1982 overcrowding in South African prisons was at a sufficiently serious level to cause Judge JPG Eksteen to state that it was one of the most important factors which prevented the rehabilitation of prisoners in South Africa. The judge pointed to comments in Parliament by the Minister of Justice to the effect that more than ninety prisons in South Africa were overcrowded, in some cases up to 309 per cent. He stated that a large percentage of prisoners were serving short terms of imprisonment. The

be reserved for hardened criminals, with petty offenders serving their sentences within the community. This would lead to a significant decrease in the South African prison population, since many of those imprisoned were petty offenders as opposed to hardened criminals. One of the main challenges faced by those advocating this idea, was that implementing community service sentences required an extensive infrastructure to be in place within the community. As an article in The Cape Times put it: "Community service means involving the community - using men and women who are prepared to give of their time without remuneration to a project which they believe can be of benefit not only to the offender but also to the community at large" in "Community Service as Alternative to Jail" 18 January 1982 The Cape Times 8. During the first half of the 1980s, community service orders did operate, but only on a very small scale. The limited extent to which such orders were employed at this time is revealed by a report in The Argus, which concerned community service orders in Cape Town. The report revealed that only forty-six persons had received community service orders since the first such order was served in January 1979. See "Alternative to Jail" 16 June 1983 The Argus 27. On 13 May 1984 the Sunday Tribune commented favourably on the fact that the Witwatersrand Local Division of the Supreme Court had, for the first time, handed down a sentence in a criminal trial which required the convicted offender to complete a period of community service under the supervision of the National Institute for Crime Prevention and the Reintegration of Offenders: "There is much to do in community service and such sentences would also promote a greater awareness of community needs while allowing the offender to continue his job and provide for his family. Money and time should be spent to organize effective supervision of such sentences. Once this is done the way will be open for courts to impose community service regularly as part of sentences which will not only ease prison overcrowding, but deal with minor offenders in an acceptably humane way" in "Sensible Sentence" 13 May 1984 Sunday Tribune 20.

26 "Prison Population 'Is a Problem'” 6 May 1982 The Citizen 3.

27 Ibid. See also the Afrikaans newspaper Beeld, which was somewhat more alarmist in its assessment of the Director-General's presentation to Parliament. Under the heading "Gevangenisdiens het 'n Krisis Ophande" - "Prison Service has a Crisis on its Hands" - its report began by stating that South African prisons were often hopelessly overcrowded and that, linked to a shortage of prison staff, there was cause for serious concern. See "Gevangenisdiens het 'n Krisis Ophande" 6 May 1982 Beeld 14. 
courts had repeatedly spoken out against short terms of imprisonment and indicated that such sentences often did more harm than good. First offenders were exposed to the negative aspects of imprisonment without being exposed to any rehabilitative influences. ${ }^{28}$

During the year which followed, the media were to keep the problem of prison overcrowding high on the public agenda. In March 1983, the Cape Herald reported that South African prisons were "bursting at the seams" with the daily average prison population standing at $102069 .{ }^{29}$ In April of that year, it was reported that South African prisons were 22,4 per cent over their capacity. The Minister of Justice, Mr Kobie Coetzee, revealed in Parliament that, according to the latest figures available to him, South Africa's prison population stood at 105 634. The Minister brushed aside concerns expressed by opposition members of parliament, including Mrs Helen Suzman, by stating that prisons all over the world were over-populated and that the situation in South Africa was not unusual. ${ }^{30}$ In an editorial under the heading "Any Room Left for Compassion?", The Star responded, inter alia, as follows:

"Well, it is unusual in that a considerable proportion of those prisoners would not be there if not for apartheid. They are 'technical' offenders against a system of colour-based laws, mostly to do with influx control, which do not exist in more normal societies. Some are there for offences against a range of sweeping security laws, while others again are detained under such laws without having been found guilty of any offence."

In an editorial with the headline "Our Overflowing Jails", The Natal Mercury was similarly scathing in its response to the somewhat callous position taken by the Minister on this issue:

"There is no more reliable growth industry in South Africa than the country's booming prison population. Notwithstanding an amnesty granted last May it has surged ahead to set a new current record of 105634 - a figure which even the Minister of Justice spoke of with 'regret' this week. Politicians, lawyers, academics and other concerned bodies have long voiced their alarm at this developing crisis. Commissions have reported on it, but still the Government seems unable or unwilling to come to grips with it ... What can one say, other than to reiterate what has been stated time and again? Much of our prison congestion is due to the arrest of thousands of blacks for influxcontrol offences and other technical infringements which are not regarded as crimes elsewhere in the world. Meanwhile there are thousands of awaitingtrial prisoners who may wait weeks behind bars before being acquitted or sentenced to a few days in jail."

In September 1983 the State President, Mr Marais Viljoen, revealed that South Africa's prisons were overcrowded by 36 per cent and that the daily prison population over the preceding three months had averaged 106000.

\footnotetext{
"Te Vol Tronke Maak Opheffing Moeilik" 11 June 1982 Die Oosterlig 5.

"South African Prisons Burst at the Seams" 26 March 1983 Cape Herald 23.

"South Africa has More than 105000 in Prison" 26 April 1983 The Star 6.

"Any Room Left for Compassion?" 27 April 1983 The Star 10.

"Our Overflowing Jails" 29 April 1983 The Natal Mercury 10. For yet another example, see the "A Nation of Too Many Prisoners" 2 May 1983 Eastern Province Herald 8.
} 
He also revealed that the cost to the country was about R700 000 per day. ${ }^{33}$ In the same month, an editorial in the Pretoria News expressed deep alarm at the situation that was developing in the prisons due to overcrowding:

"There have long been too many prisoners in South Africa, partly because of the multitude of laws (and the near impossibility of observing some of them) designed to prop up apartheid. The legacy of this has struck the Prisons Department with full force. As the Minister of Justice, Mr Kobie Coetzee, said yesterday: the ratio of warders to prisoners in South Africa is one to 12. In some European countries it is one to one ... The situation has now arrived where hard-pressed Prisons staff appear in danger of being overwhelmed ... Mr Coetzee ... calls for greater emphasis on hand combat training for prison warders. One will be forgiven for the impression that it's beginning to sound a little like a war out there."

In October 1983, The Daily News made the following important point about the hidden costs of imprisoning thousands of ordinary South Africans for offences against social control legislation:

"The news that South Africa's prisons are overcrowded by 36 percent helps explain how maladminstration and violence, as revealed in the Barberton prison trial, can occur. The irony is that the daily prison population of 106000 could be considerably cut by decriminalising many statutory crimes, such as pass offences. Every prisoner costs the country R6,52 a day - but the cost in terms of lingering bitterness is incalculable."

Two days after the publication of the above report, a strongly-worded editorial in The Natal Mercury reflected the editor's considerable sense of frustration at the fact that the Government appeared incapable of properly getting to grips with the problem of prison overcrowding:

\begin{abstract}
"Apart from a periodic wringing of hands and some appropriate words about the gravity of the position, the Government's responses down the years to the country's burgeoning prison population have been memorable mostly for their inadequacy ... Commissions have reported on the situation, and numerous politicians, lawyers, academics and other concerned people have contributed their thoughts. But still the Government refuses to come to grips with fundamental causes of the overcrowding ... [M] uch or the prison congestion is due to the arrests of thousands of blacks for influx control offences and other technical infringements which are not regarded as crimes elsewhere in the world. This has led to the unhappy situation where many blacks regard a spell 'inside' more as an acceptable hazard of life than a stigma. Meanwhile there are thousands of awaiting-trial prisoners who may wait several weeks behind bars before being acquitted or sentenced to a few days in jail.'
\end{abstract}

Later during the same month, a report in the Pretoria News noted that, between 1970 and 1980, South Africa's prison population had risen by twelve per cent, whereas the population of the country had only risen by

33 "SA Prisoners Cost us R700 000 a Day" 14 September 1983 Pretoria News 5. See also "Prisons Crowded 36 pc says Viljoen" 14 September 1983 The Natal Mercury 1; "Overcrowing Crisis in SA's Prisons" 14 September 1983 The Citizen 8; and "Prisons Upkeep R700 000 a Day 15 September 1983 The Citizen 18.

"A War out There?" 16 September 1983 Pretoria News 8.

"Cost of Jailing" 4 October 1983 The Daily News 16.

36 "Crowded Jails" 5 October 1983 The Natal Mercury 14. 
seven per cent. ${ }^{37}$ On the same day, The Star published a report under the alarming headline "Gross overcrowding allied to understaffing creates 'timebomb"'. The report pointed out, that although South African prisons were overcrowded by an overall average of 36 per cent, certain individual prisons were overcrowded by a much greater percentage - some by as much as 300 per cent. ${ }^{38}$ In another report published in The Star on the same day, it was pointed out that, due to significant prison-staff shortages ${ }^{39}$ as well as a large turnover of prison staff, ${ }^{40}$ the ratio of trained prison-staff members to prisoners was one to 635 . This rendered the rehabilitation of prisoners "extremely difficult if not impossible". ${ }^{41}$ It was also reported that there was a chronic shortage of social workers and only 23 psychologists to care for the prison population. ${ }^{42}$ An editorial in the same newspaper the following day summed up the major problems faced by the South African penal system, inter alia, as follows:

"Chief cause for concern is overcrowding - 25 percent on average at the country's 242 prisons - closely followed by an alarming 20 percent shortage of warders ... Inevitably, the cry is for more prisons and more staff. If ever there was an example of tackling a problem the wrong way, this is it. Switching the objective to fewer prisoners makes much more sense; although that would be no panacea, it would serve as an excellent palliative. For those who commit serious crimes - particularly of a violent nature - there is of course no alternative to a jail sentence. But far too many people are locked up for minor offences, a large proportion stemming from the political system. Abolish apartheid measures such as influx control and the Group Areas Act and there would be an immediate, significant fall in the prison population."

The public pressure brought to bear by such reports must have taken their toll on the apartheid Government. One indication of this is that the start of the new year witnessed an effort by the conservatively-inclined newspaper Die Vaderland to shift the public debate onto a track less critical of the authorities. In January 1984 the newspaper published a number of articles on the question of overcrowding in South African prisons. Among other sources, it solicited the views of Mr FW Krügel, the chairman of the working group which had been set up in 1981 in order to investigate the problem of

37 "Prisons Service has Tough Challenge" 14 October 1983 Pretoria News 3; and see also "Behind SA's Prison Bars" 15 October 1983 Pretoria News 10.

38 "Gross Overcrowding Allied to Understaffing Creates 'Time-bomb" 14 October 1983 The Star 11.

39 It was reported that there were 1318 vacant posts in the Prisons Service at that time.

$40 \mathrm{Eg}$, it was reported that, at that time, 53 per cent of the 3454 white prison warders had fewer than two-years' experience.

41 "Staff and Cash Crisis Face SA Jail Service" 14 October 1983 The Star 1. Just one of the indicators that those confined within the South African penal system at this time were unlikely to be rehabilitated, was the fact that the number of prisoners involved in formal study was shockingly low. The total prison population at this time was around 106,000 and, according to a report in the Pretoria News on 14 October 1983: "Only 700 prisoners were registered for formal study last year while 1900 were involved in literacy training." See 14 October 1983 Pretoria News 3.

4214 October 1983 The Star 1; see also "Difficult Times for Prison Service" 15 October 1983 Weekend Argus 4; and "Some of the Facts and Figures Given" 15 October 1983 Pretoria News 10.

43 "Give Prisons a Break" 15 October 1983 The Star 10. 
overcrowding on an ongoing basis. According to Krügel, the problem of overcrowding in South African prisons had improved since the time of the Viljoen Commission in 1976, but there was still much room for improvement. He stated that it was not simply the apartheid legal system which lay at the heart of the problem, but the socio-economic condition of the country as a whole. Further, Krügel expressed the opinion that the situation in relation to overcrowding in prisons was better in South Africa than in many other countries. ${ }^{44}$ Krügel was supported in this opinion by the Commissioner of Prisons, Lieutenant-General Willem Willemse. Willemse characterized overcrowding in South African prisons as "mild". 45 This was despite the fact that, by his own admission, South African prisons were overcrowded by 22,4 per cent. ${ }^{46}$ Although this figure indicated that there was a problem, according to Willemse it compared favourably to the figures for certain other countries, such as 40 per cent in France, 60 per cent in Italy and 89 per cent in certain American prisons. ${ }^{47}$ In the South African context, Willemse pointed out that it was prisons near cities, which served as reception centres for large numbers of awaiting-trial prisoners and contained large numbers of short-term prisoners, which tended to be most overcrowded. ${ }^{48}$

Die Vaderland seized on Willemse's opinion that South African prisons were only "mildly" overcrowded. The newspaper published an editorial under the headline "We compare favourably", as well as an article under the headline "South Africa is not experiencing a crisis". ${ }^{49}$ In its editorial, Die Vaderland stated that much of the criticism in relation to overcrowding in South African prisons was "uninformed and out of context". ${ }^{0}$ At the same time, the newspaper pointed out that the prison authorities had to carry a great deal of the blame for the lack of information on the part of its critics. After all, the authorities were responsible for the measures which kept prisons out of the public spotlight and discouraged people from becoming properly informed. But the critics could not be excused, said Die Vaderland, for comparing the South African penal system solely to the penal systems of Western countries. South Africa was part of both the "Third World" and "The West" and this would be reflected in its prison population. Seen in that light, South Africa compared favourably to other countries since, at the very least, South African prisons met basic standards in relation to the provision of adequate light, air, medical facilities and recreational facilities. ${ }^{51}$

Unfortunately for Die Vaderland, the fact of chronic overcrowding in South African prisons could not be wished away. In March 1984 the issue once again received extensive negative coverage in the mainstream South African media. In response to a parliamentary question, the Minister of Justice

\footnotetext{
"Tronkstraf vir Klein Misdade Skep Probleme" 10 January 1984 Die Vaderland 9.

"Matig".

"Oorbevolking in SA Gevangenisse" 10 January 1984 Die Vaderland 9.

"Óns Vergelyk Gunstig" 11 January 1984 Die Vaderland 8.

10 January 1984 Die Vaderland 9.

11 January 1984 Die Vaderland 8; and "Suid-Afrika Beleef nie 'n Krisis nie" 10 January 1984 Die Vaderland 9.

50 The words used were "oningelig en buite verband". See 11 January 1984 Die Vaderland 8.

5111 January 1984 Die Vaderland 8.
} 
revealed that while the South African prison system had been designed to accommodate 74378 prisoners, in December 1983 the daily average prison population in South Africa was 105 509.8. The Minister provided a list of no fewer than 33 prisons which were overcrowded by more than 100 per cent. Eight of these prisons were overcrowded by more than 200 per cent, and one by more than 300 per cent. The most overcrowded prison in the country was Fauresmith in the Free State at 352 per cent. Opposition Member of Parliament, Mr David Dalling, ${ }^{52}$ expressed his "shock" at these figures, claiming that the real problem was that too many people were jailed "unnecessarily for technical offences such as the pass laws and curfew regulations". ${ }^{53}$ The Natal Mercury castigated the Minister for downplaying the extent of the problem and pointed perceptively to the wider social causes of prison overcrowding:

"Last year the Minister of Justice spoke with 'regret' of a new record in the prison population. This year he has referred with masterly understatement to a 'mildly overcrowded' situation ... The Government should be looking not so much to new prisons as to the dismal quality of life in the rural areas, which causes thousands to migrate to the cities in search of jobs. It is here that so many get caught up in the web of statutory offences that lead to prison sentences and often weeks behind bars as awaiting-trial prisoners. The sobering prognosis given this week at the seminar of the Mayor's Steering Committee in Durban was that by the year 2000 'a cascade' of people from poor rural areas could be expected, as the living standards of rural blacks would improve about 29 times if they moved to urban areas ... As long as the Government fails to meet these challenges, and balks at decriminalising certain statutory offences, it must not be surprised if its jails overflow."

Other mainstream South African newspapers expressed similar opinions. An editorial in The Natal Witness castigated the Minister of Justice for stating that the prisons were only "mildly" overcrowded, and characterized the Minister's comments as "callous". 55 The Afrikaans newspaper Beeld took the Minister to task for raising the excuse that, during the day, prisoners spent most of their time working outside, meaning that there was plenty of room inside. With heavy irony, the newspaper summed up the Minister's attitude as follows: "Well, do you want to sleep or do you want to break stone?"56 In an editorial dripping with irony, The Daily News commented, inter alia, as follows:

"Prison overcrowding takes on a new dimension when it appears that Minister of Justice and Prisons, Mr Kobie Coetsee, has some sort of grading system that describes present conditions as simply 'mildly overcrowded' ... Whether in the Minister's book the overcrowding is 'mild', 'semi-mild' or 'slightly mild', the daily prison population has to be seen in world terms, or more specifically in western world terms. (The Government, after all, insists that it is a beacon of western enlightenment at the tip of the Dark Continent.)"

\footnotetext{
Progressive Federal Party - Sandton.

The Cape Times 7 March 1984 "SA prisons overcrowded" at page 4.

The Natal Mercury 8 March 1984 "Our overflowing jails" at page 16.

The Natal Witness 8 March 1984 "Prisons overcrowding" at page 10.

56 The question was phrased as follows: "wil julle slaap of wil julle klippe breek?" See "Méér as Vyfster-vol" 8 March 1984 Beeld 15.

57 "Mildly Disturbing?" 10 March 1984 The Daily News 8.
} 
The caustic comment that the Minister should be held to a "western" standard must have been particularly galling to the authorities. Overall, public debate on the issue of prison overcrowding between the years 1981 and 1984 was strongly critical of the policies adopted by the apartheid Government. Considerable ideological pressure was brought to bear on the regime by constantly turning the knife - the inescapable fact that South African prisons remained stubbornly overcrowded.

\section{THE HOEXTER COMMISSION REPORT AND THE DEBATE ON PRISON OVERCROWDING}

In April 1984, the Hoexter Commission once more took centre stage in the debate on prison overcrowding. Public concern on the issue reached boiling point as the media reported on the findings of the Hoexter Commission into the structure and functioning of the courts. The Commission eschewed a narrow focus on the particular area it had been asked to investigate - the structure and functioning of the courts - in favour of a more integrated "bigpicture" approach. It insisted on exposing the link between the structure and functioning of the courts on the one hand, and the chronic overcrowding within the penal system on the other. It then sought to tie the problem of prison overcrowding to the economic, social and political realities of South Africa. In the words of the Commission:

"On the face of it, the overcrowding of prisons appears to have little bearing on the functioning of the courts. In the commission's opinion, however, the overcrowded prisons of our country are a dismal social phenomenon closely linked to the whole system of justice.

The Commission stated that the problem of prison overcrowding was intimately related to the fact that prisons were being used as a form of social control. The clear message conveyed to South Africans through newspaper reporting on the Commission's findings, was that a major cause of overcrowding was the racist social-control policy of the apartheid Government. The findings of the Commission also made it clear that there was a broader social and economic dimension which underpinned the entire problem - that is, the problem of inequality and widespread poverty, particularly in the rural areas, which was bound to result in an unstoppable wave of urbanization as rural people sought to better their lives. Under the headline "Many should not be in prison at all", The Argus reported that the Hoexter Commission had found that South Africa had one of the biggest prison populations in the world and that "large numbers of people" should not be in prison at all. Inter alia, the newspaper quoted the following interesting extract from the Commission's findings:

"A material factor in regard to the overcrowding of our prisons is that hordes of blacks land in prison as a result of influx control. Judged by civilised norms, these people are not real malefactors. They are the needy victims of a social system that controls the influx of the people from the rural to the urban areas

58 "Overcrowding of Jails Linked to System of Justice" 6 April 1984 The Citizen 10. 
by penal sanctions. The reason for this virtual unstemmable influx is poverty."

The consequences of this state of affairs, where thousands upon thousands of ordinary breadwinners were being crammed into prisons for committing technical social-control offences, alongside hardened criminals, were deeply disturbing. According to the Commission, this unhappy state of affairs resulted in "a two-fold psychological effect on the largest population group in the country". ${ }^{60}$ The Citizen summarized this negative psychological effect as follows:

"In the first place the commission says, it breeds in many Blacks especially those who have actually suffered the shame and indignity of imprisonment for minor offences, contempt for the administration of justice in general and the criminal courts in particular. In the second place the result was that, contrary to sound social norms, the serving of a prison sentence was no longer regarded as a stigma by many Blacks, and that imprisonment as a punishment for the commission of a crime was consequently losing its power as a deterrent."

A further negative consequence of chronic overcrowding identified by the Commission was related to the length of sentences served by long-term prisoners. The Commission pointed out that overcrowding could lead to the premature release of serious criminals sentenced to longer terms of imprisonment. Interfering with the carefully considered sentences passed by the courts could negatively affect the rehabilitation of such criminals. ${ }^{62}$ In the words of the Commission:

"An immediate and inevitable result of overcrowded prisons is that convicted persons on whom a long term of imprisonment has been imposed are released prematurely for the reason that prison accommodation is limited rather than that they merit release on parole. This at once defeats the criminal court's carefully considered sentence and the rehabilitative object of a prison sentence.'

As far as the effects of overcrowding on gang activity were concerned, the Commission stated that it was quite frequently the case that "20 or 30 vicious thugs" were forced to sleep together in a single cell. The Commission commented that:

"This unhealthy state of affairs breeds gangsterism; and in particular it leads to the utterly callous and gruesome murder, by the members of a gang, of a defenceless cell-mate who for some reason has incurred their wrath.

The Hoexter Commission's unequivocal finding that the chronic overcrowding in South African prisons was linked to the apartheid system of social control, and that it was untenable to allow the situation to drag on, was driven home in the public mind by a number of articles in the country's

59 "Many Should not be in Prison at All" 5 April 1984 The Argus 6.

606 April 1984 The Citizen 10.

61 Ibid.

62 April 1984 The Argus 6.

636 April 1984 The Citizen 10.

64 “Hoexter Probe Slams Influx Control Laws" 6 April 1984 Rand Daily Mail 7. 
newspapers. The headlines to these articles reflected a tone which was extremely critical of the apartheid Government:

"Hoexter probe slams influx control laws"65

"SA tronke hieroor oorvol" ["South African prisons are overcrowded because of this"]

"Social system 'jails hordes"”67

"SA jails crammed with technical offenders - Hoexter probe puts the courts on trial"

"SA's tragedy: prisoners who are not criminals." ${ }^{\text {"99 }}$

The Weekend Argus called the Hoexter Commission's report a "devastating indictment of the Government's policies" and predicted that it would "blow up into a major political storm when the opposition and the Government square up to each other in a special debate". ${ }^{70}$ Under the headline "SA's tragedy: prisoners who are not criminals", the Evening Post referred approvingly to the work of the Hoexter Commission as having "opened to fresh air a festering sore". ${ }^{71}$ The newspaper submitted the following dramatic and depressing assessment of the Hoexter Commission's findings:

"The gap between the law makers (the Government) and the judiciary - in other words those who mete out justice - may be close to unbridgeable. Law and justice cease to mean the same thing or even be on the same side when innocents are thrown together with hardened criminals in police cells to await trial and later, when convicted of minor technical offences, in overcrowded jails. There is no space in the cells to accommodate the killers and the innocents separately. So they are thrown in together, the innocents forced, so often, to share the excesses of the vicious and depraved. They watch in terror as thugs slice each other to death using knives and razor blades, smuggled into prison in all sorts of ways. There is a plethora of evidence of this from our own Supreme Court."

Reflecting an old theme characteristic of the South African penal system stretching back to colonial times - that is, that overcrowded South African prisons were, in fact, "universities of crime" - the Evening Post challenged its readers to answer the following rhetorical question: "How many ... gangsters became gangsters after being forced by the overcrowded system to spend time with veteran mobsters?"73

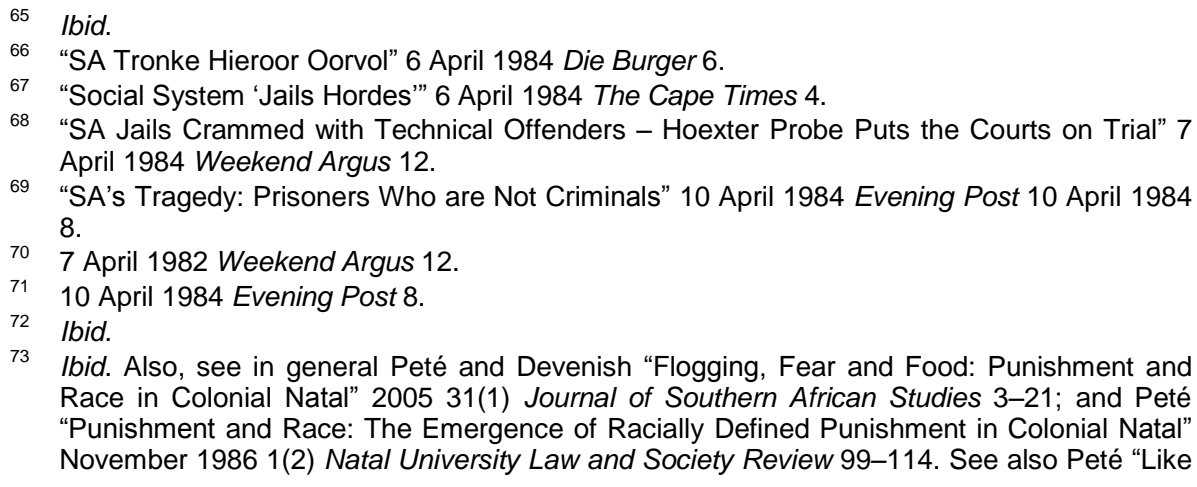

Ibid. Also, see in general Peté and Devenish "Flogging, Fear and Food: Punishment and Race in Colonial Natal" 2005 31(1) Journal of Southern African Studies 3-21; and Peté "Punishment and Race: The Emergence of Racially Defined Punishment in Colonial Natal" November 1986 1(2) Natal University Law and Society Review 99-114. See also Peté "Like 
The parliamentary opposition seized on the Hoexter Commission report in order to direct a heavy critical broadside at the Government. Mr David Dalling, the spokesman on justice for the Progressive Federal Party, labelled the report a "public crucifixion of Nationalist complacency, indifference, insensitivity, inefficiency, bureaucracy, incompetence, indolence, racial prejudice and bluster in the area of justice administration in our country". ${ }^{74}$ The conservatively-aligned newspaper The Citizen responded to Dalling's comment by stating that:

"We doubt whether the commission would see its report in that light - and even as a politician seeking to make capital out of the report, Mr Dalling goes beyond reason, stringing together a lot of words as if he had swallowed a dictionary."

The Government responded by stating that the Progressive Federal Party's "political and unfounded" use of the report was deplorable and would do nothing beneficial for justice in South Africa. ${ }^{76}$

The Hoexter Commission Report was debated in Parliament on 12 April 1984. The Minister of Justice, Mr Kobie Coetsee, admitted that the Government was concerned about the problem of prison overcrowding. Despite efforts by the Government to address the problem, the extent of overcrowding had been reduced from only 46 per cent to 41,8 per cent. Coetsee claimed that influx-control offenders made up only 7,09 per cent of the country's prison population. ${ }^{77}$ The Government was investigating the feasibility of building new prisons to alleviate the problem. The Minister pointed out that minimum-security prisons could be built at a much lower cost and in a much shorter time than maximum-security prisons. ${ }^{78}$ It is not clear whether the Government actually believed that it could "build its way out" of the problem of prison overcrowding, or whether it was simply raising the issue as a smokescreen to deflect the severe criticism directed at it in the media. What does seem to be clear is that, with the figures on prison overcrowding clearly indicating a serious problem, and the opposition making the link between between prison overcrowding and the disastrous social-control measures implemented by the apartheid regime, the tone of the Government's response was defensive and focused particularly on deflecting the heavy critique directed at it.

a Bad Penny: The Problem of Chronic Overcrowding in the Prisons of Colonial Natal 1845 to 1910 - Parts One and Two" forthcoming publications.

"Hoexter Report" 7 April 1984 The Citizen 7 April 19846.

75 Ibid.

7 April 1984 Weekend Argus 12.

7 In December 1984 it was reported that, according to a special survey conducted on 15 March of that year, a total of 7,480 prisoners (both sentenced and unsentenced) were in prison due to violations of influx-control measures. The total number of sentenced and unsentenced persons detained in South African prisons of the day in question was 108,246. Those detained due to violations of apartheid influx-control measures on 15 March 1984 thus represented 7,09 per cent of the total South African prison population. See"Prison Service Maintains Professional Standards" 20 December 1984 The Argus 35.

78 "More Prisons to be Built" 13 April 1984 The Cape Times 4; see also "Regering Aanvaar LLB-vereiste" 13 April 1984 Die Vaderland 4; and "More Prisons Needed" 13 April 1984 The Citizen 4. 
The conservatively-inclined newspaper Die Vaderland latched on to the Minister's contention that influx control was not the main reason for chronic overcrowding in South Africa's prisons. Under the headline "Pass offenders only 3,9 per cent of prison population", the newspaper ran a story citing the National Party Member of Parliament for Kroonstad, Mr Willie Breytenbach, who stated that, according to a census of the prison population conducted on 31 January 1983, only 4170 of the more than 103000 persons in prison on that day were influx-control offenders. Removing the influx control offenders completely from the equation would have reduced overcrowding in South African prisons on that day from only 41,3 per cent to 35 per cent. In line, perhaps, with the general "laager mentality" of those within the ruling party at this time, Breytenbach emphasized that prison overcrowding was not a problem which was unique to South Africa. ${ }^{79}$

The more liberal South African newspapers were loathe to accept the contention that South Africa's infamous pass laws were only a minor factor contributing to overcrowding in South African prisons. Under the headline "Disbelief Greets Official Tally of Pass Law Inmates", the Eastern Province Herald published an article sceptical of the claim by the Minister of Justice that only 7,09 per cent of South African prisoners were influx-control offenders. The article cited the views of Helen Suzman, the Progressive Federal Party spokesperson on Justice, who stated that she simply did not believe the Minister. It also cited the views of Mrs Joyce Harris of the Black Sash, who stated that she would be extremely surprised if the figure of 7,09 per cent was correct and said that she thought Helen Suzman was "much more likely to be correct". ${ }^{80}$ Suzman stuck to her guns when, on 18 May 1984 during a debate in Parliament, she once again drew the attention of the Government to the chronic overcrowding in South African prisons. According to a report in The Citizen, Suzman suggested to the Minister of Justice that he should tell his cabinet colleagues that the overcrowding in prisons, which was due to influx-control laws, was intolerable and that something should be done about it. She suggested to the Minister that he "take the Hoexter, Van Dam and other reports on the system of justice in South Africa and 'shove them under the noses' of his Cabinet colleagues". ${ }^{81}$ Suzman also called for the appointment of a permanent monitoring body, appointed from outside the Prisons Service, to conduct regular inspections of prisons. Certain National Party members of Parliament accused Suzman of "misusing" the debate on the Prisons' budget vote to attack the Government. ${ }^{82}$

During the first half of the 1980s, South Africans were involved not only in a physical struggle, but also in an ideological struggle. The fact of chronic overcrowding in South African prisons during this period was used as ideological weapon by those opposed to the apartheid regime. While those who supported the apartheid Government sought to minimize the overall role played by apartheid social-control legislation in aggravating the problem,

\footnotetext{
"Pasoortreders net 3,9 ps. Van Tronkvolk" 13 April 1984 Die Vaderland 4.

30 "Disbelief Greets Official Tally of Pass Law Inmates" 14 April 1984 Eastern Province Herald 3.

81 "Prison Overcrowding is Intolerable - Suzman" 19 May 19844.

82 "Call for a Monitoring Body to Inspect Prisons" 19 May 1984 Weekend Argus 3.
} 
those who opposed the regime sought to maximize its role. Whatever figures are used, it is clear that apartheid social-control legislation did play a significant role in prison overcrowding at the time. It is equally clear, however, that apartheid social-control legislation was not solely to blame for the problem. It should have been obvious to all concerned in the ideological debate that the roots of prison overcrowding lay much deeper than apartheid social-control legislation. Deep economic inequalities, as well as gaping social and political divides, stretching back decades and even centuries had an equally important role to play. As bitter experience during the postapartheid period was to prove, simply removing influx control and the pass laws would not magically solve the deep-seated problem of prison overcrowding.

\section{CORPORAL PUNISHMENT AS A POSSIBLE "SOLUTION" TO PRISON OVERCROWDING}

Of all the possible "solutions" proposed to deal with the problem of prison overcrowding in the first half of the 1980s, one of the most interesting was the suggestion that, wherever possible, corporal punishment should be used as an alternative to imprisonment. ${ }^{83}$ Although there is no evidence that the suggestion was ever implemented, one of the reasons that it is worthy of further discussion lies in the fact that it ties in with a theme which was prominent within South African penal discourse during colonial times - that is, that corporal punishment was a particularly suitable punishment for dealing with black offenders. ${ }^{84}$ Despite the fact that whipping was a form of punishment more at home in the eighteenth than in the nineteenth century,

83 See, eg, Die Vaderland 5 February 19811 . Note that the proposed increase in the use of corporal punishment was not the only "strange" suggestion made to improve penal policy during this period. In August 1984, in an article intriguingly entitled "Use prisoners as guinea pigs - vet", The Daily News reported on a bizarre suggestion by a certain Dr Brian Wessels, made during a lecture at the University of Natal. According to the report Dr Wessels, who was a veterinarian, suggested that long-term prisoners be allowed to "repay their debt to society by volunteering to be subjects in medical experiments". The report went on to describe the rationale for this bizarre suggestion, inter alia, as follows: "[l]f prisoners, excluding non-violent political prisoners, could give their permission for the research knowing the consequences of the experiments, they would not be a burden on society. Commercial firms would pay a fortune to have live volunteer subjects in a closed environment for their experiments. The prisoners could also in this way earn money to support their families." See "Use Prisoners as Guinea Pigs - Vet" 9 August 1984 The Daily News 6.

84 See the following articles on the use of corporal punishment as a weapon of "last resort" when confronted with intractable social problems, and as a particularly suitable form of punishment for black offenders: Peté and Devenish 2005 31(1) Journal of Southern African Studies 3-21; Peté November 1986 1(2) Natal University Law and Society Review 99-114; Peté "Spare the Rod and Spoil the Nation?: Trends in Corporal Punishment Abroad and its Place in the New South Africa" 19943 South African Journal of Criminal Justice 295-306; Crocker and Peté "Letting Go of the Lash: The Extraordinary Tenacity and Prolonged Decline of Judicial Corporal Punishment in Britain and its Former Colonies in Africa (Part 1)" 2007 28(2) Obiter 271-290; Crocker and Peté "Letting Go of the Lash: The Extraordinary Tenacity and Prolonged Decline of Judicial Corporal Punishment in Britain and its Former Colonies in Africa (Part 2)" 2007 28(3) Obiter 465-501. 
the ideological power retained by this form of punishment in the penultimate decade of the latter century is significant.

During his evidence before the Hoexter Commission in February 1981, General Brink expressed the view that, in certain cases, it was preferable to sentence an offender to corporal punishment than to imprisonment. He made it clear that he was speaking in his personal capacity and that he was not a supporter of compulsory corporal punishment. He pointed out, however, that imprisonment often brought with it a degree of disruption to the offender and his family. For example, on being imprisoned the offender might lose his employment. Sentencing certain petty offenders to corporal punishment as opposed to imprisonment, would reduce the degree of disruption experienced by those offenders. ${ }^{85}$

Three years later, in April 1984, corporal punishment once again became part of the public discourse when the Sunday Tribune broke the news that a secret Department of Justice document had proposed an increase in sentences of corporal punishment as an alternative to imprisonment, in order to cut down on prison overcrowding. In a dramatic report under the headline "Cane the criminal: Whippings will ease prison overcrowding - secret report", the Sunday Tribune alleged that South Africa had "the most prisoners per capita in the world" and that certain prisons were overcrowded by almost eighty per cent. ${ }^{86}$ According to the report, one of the proposals put forward by a Department of Justice working group investigating ways of reducing the prison population, was to increase the number of offences for which whippings could be imposed, as well as to increase the age limit beyond which whippings could no longer imposed. ${ }^{87}$ If accepted, this latter proposal would have extended an antiquated and brutal form of "sanguinary" punishment to offenders who could, by no stretch of the imagination, be classed as "juveniles". At this time juveniles were the only group deemed suitable to receive corporal punishment. The fact that this antiquated form of sanguinary punishment was being seriously considered as a possible solution to prison overcrowding at this time should not be all that surprising. The temptation to resort to corporal punishment as a "quick fix" in times of stress, is a very old theme within South African penal history, stretching back to colonial times. ${ }^{88}$

The increased use of corporal punishment was supported by the Deputy Attorney General of the Transvaal, Dr JA van S D'Oliveira, who believed that "whipping was not more humiliating than imprisonment and would teach a short, sharp lesson". ${ }^{89}$ It appears, however, that D'Oliveira was in the minority. According to the Sunday Tribune, a confidential document had

85 "Tronke in SA Oorvol, Getuig Generaal" 5 February 1981 Oggendblad 5.

86 "Cane the Criminal: Whippings will Ease Prison Overcrowding - Secret Report" 15 April 1984 Sunday Tribune 4.

87 It was proposed that the age limit be increased to 29 .

88 See in general: Peté and Devenish 2005 31(1) Journal of Southern African Studies 3-21: Peté November 1986 1(2) Natal University Law and Society Review 99-114; Peté 19943 South African Journal of Criminal Justice 295-306; Crocker and Peté 2007 28(2) Obiter 271-290; Crocker and Peté 2007 28(3) Obiter 465-501.

8915 April 1984 Sunday Tribune 4. 
been sent to the judiciary and the Bar, outlining the proposals relating to corporal punishment, which had elicited a significant degree of opposition. The newspaper quoted a string of experts expressing their strong opposition to the proposed expansion of corporal punishment within South Africa's penal system. The Chairman of the General Council of the Bar was quoted as stating that: "Whipping is a particularly brutal punishment which civilised societies should avoid." 90 The director of the Centre for Applied Legal Studies at the University of the Witwatersrand, Professor John Dugard, condemned the proposals a "crazy and barbaric" and stated that: "Corporal punishment has no place in the 20th Century." ${ }^{\prime \prime 1}$ Dugard pointed out that the European Court of Human Rights had condemned judicial corporal punishment as inhuman and degrading, and that the United States of America had abandoned this form of punishment in 1968 when it was found to be unconstitutional on the grounds of cruelty. According to Dugard: "The way to reduce prison population is to repeal the host of racist laws and introduce a more effective system of probation." ${ }^{92}$ Professor David McQuoidMason of the University of Natal stated that: "While most criminologists agree that prison is not the most suitable place for trying to resocialise or rehabilitate criminals, that does not mean resorting to semi-barbaric sentences." ${ }^{.93}$ The head of Criminology at the University of Durban-Westville, Graser, expressed the opinion that corporal punishment was "not effective as a deterrent and has no rehabilitative effect" and concluded bluntly that: "It merely brutalises." ${ }^{44}$ According to Graser, violent punishment could make offenders more violent, creating a "vicious circle". ${ }^{95}$ Finally, the Sunday Tribune quoted from the 1965 judgment of DG Fannon, a former judge of the Supreme Court in the Natal Provincial Division:

"Whipping is a punishment of a particularly severe kind. It is brutal ... and constitutes a severe assault upon not only the person of the recipient, but upon his dignity as a human being."

When contacted by the newspaper, the former judge expressed the opinion that South Africa should be limiting corporal punishment rather than extending it. In an editorial under the title "Degrading proposal", the Sunday Tribune summed up its opinion on the proposal inter alia as follows:

"It appears to be one of the peculiarities of the Government that as one section attempts reforms, another moves inexorably in the opposite direction. The Department of Justice is circulating a proposal that, in order to ease prison overcrowding, greater use should be made of whipping ... A more misguided approach would be difficult to imagine. The Hoexter Commission has already identified the prime cause of overcrowding. It is the race laws which make criminals of decent people convicted for the 'crime' of seeking a living. Whipping is a particularly brutal punishment. It is an assault not only on the person, but on human dignity. It brutalised the recipient, the persons and

\footnotetext{
Ibid.

Ibid.

Ibid.

Ibid.

Ibid.

Ibid.

Ibid.
} 
the society administering it. Medieval in concept, whipping has no place in a civilised judicial system ... [l]f the Government accepts the thrust of the Hoexter Commission's thinking this repugnant idea will be abandoned immediately."

Ten days later on 25 April 1984, The Natal Mercury carried a report entitled "Whipping as an expedient slammed by lawyers". Inter alia, the article cited the views of the President of the Natal Law Society, Mr Tony Brokensha, who was quoted as stating that: "In my view whipping is seldom appropriate other than for juveniles to whom the alternative would be either prison or reformatory." ${ }^{98}$ The article also went into grisly detail - provided by Dr JA van S D'Oliveira who was one of the few supporters of corporal punishment at this time - about the way in which a sentence of corporal punishment was carried out in practice:

"Juveniles were caned while wearing their trousers but seniors were stripped and a protective cloth was placed over their naked buttocks to prevent cutting and bleeding and their kidneys were padded. Their hands were either tied to a frame or held away from the buttocks to prevent arm injuries. The maximum amount of cuts were seven."

Dr D'Oliveira could not tell the newspaper how much force went into each blow, but confirmed that it was "very considerable". ${ }^{100}$ Reading these extracts - even taking into account that the debate took place during the brutal apartheid years - one may be forgiven for thinking that the article relates to a discussion of penal policy which took place in 1884, as opposed to 1984. A cutting editorial in The Daily News on 25 April 1984 summed up the disapproval felt by most commentators at this time:

"It really is dismaying to find in 1984 almost enthusiastic endorsement by the Department of Justice for whipping as a punishment ... [A]s Mr Justice Didcott said last week, flogging stoops to the level of the criminal it punishes - 'This is not the time for putting the clock back'. Quite. There are other, more civilised, ways of reducing the jail population: by eliminating certain statutory crimes, such as influx control offences, for a start."

Even though, as indicated above, the arguments in favour of the extension of corporal punishment were firmly rejected by most commentators in the mid 1980s, their re-appearance more than seventy years after the end of the colonial period is significant. Firstly, it illustrates the ideological power of whipping as form of punishment. Secondly, it indicates a dysfunctional penal system characterized by the endless repetition of sterile debates. Indeed, it is interesting to note that even during the post-apartheid period, corporal punishment was suggested as a possible "solution" to chronic overcrowding in the South African penal system.

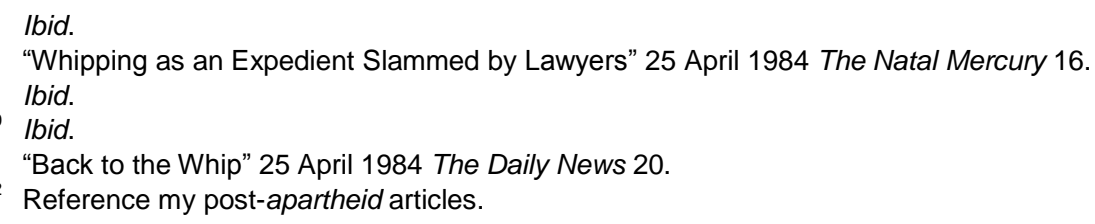




\section{$6 \quad$ CONCLUSION}

It has been argued in this article that public debates on the issue of prison overcrowding throughout the first half of the 1980s held up a mirror to South African society, in which those willing to look could see reflected the inevitable demise of the apartheid system. Open discussion in the media of the legislative restrictions which prevented free reporting about conditions in South African prisons provided opponents of the apartheid system with a platform to lambast the Government for its censorship of information. Furthermore, the extensive public debate which took place throughout the period examined on the clear link between prison overcrowding and the continued enforcement of apartheid social-control measures, must have made it clear to all but the most closed-minded supporters of the system that these measures could not be maintained indefinitely. Those who followed the debates in the mainstream national newspapers would have known that imprisoning large numbers of ordinary black citizens for petty offences against social-control legislation was creating a long-term legacy of hatred and rage; that the deterrent effect of imprisonment was being eroded in the eyes of the black community; that the prisons had been turned into "Universities of Crime" by imprisoning large numbers of petty offenders alongside "real" criminals; and that the chronic overcrowding in South Africa's prisons was tarnishing the already poor image of the country in the eyes of the global community. They would have noted that not a year went by when overcrowding was not a major issue of public debate, and that the highly-respected Hoexter Commission placed much of the blame squarely on the policies of the apartheid Government. Finally, they would have detected a hint of desperation in the suggestion that part of the solution to overcrowding could be found in the increased use of corporal punishment, an antiquated and discredited form of dealing with offenders.

Apart from holding up a mirror to apartheid South Africa, it has been suggested in this article that the debates which took place during the first half of the 1980s are tied in with a much broader and longer-term public and academic discourse on the issue of prison overcrowding. Overcrowding was not unique to the apartheid period, but has remained a consistent feature of the South African penal system from its inception to the present day. Following the debates which took place during the first half of the 1980s, one is struck by the similarities with debates which took place during the colonial period, as well as the post-apartheid period. Indeed, the debates are characterized by the repeated identification of the same problem, together with the same set of "solutions", which are repeated year after year, decade after decade, and from one century to the next. Clearly, the problem of chronic overcrowding in South Africa prisons has deep roots and is inextricably linked to intractable social and economic ills, such as extreme poverty and inequality. It may even be that overcrowding is structurally intertwined with imprisonment as a form of punishment. 